Maciej Bachryj-Krzywaźnia

Uniwersytet Wrocławski

\title{
Filozoficzne ramy i przesłanki zróżnicowania podejścia interpretacjonistycznego
}

DOI: $10.19195 / 1643-0328.21 .1$

Słowa kluczowe: podejście interpretacjonistyczne, aprioryzm, antykartezjanizm, antynaturalizm, konstruktywizm, paradygmat

\section{Wprowadzenie - w poszukiwaniu paradygmatu}

W swojej słynnej Strukturze rewolucji naukowych Thomas Kuhn posługuje się pojęciem „nauki normalnej”, czyli takiej, która wynika z przeszłych osiągnięć naukowych akceptowanych przez społeczność uczonych i traktowanych jako fundament dalszej praktyki. Związane z nim pojęcie paradygmatu wskazuje na istnienie pewnych akceptowanych wzorów faktycznej praktyki naukowej, tworzących zwartą tradycję badań, mających być świadectwem dojrzałości dyscypliny naukowej ${ }^{1}$. W ten sposób Kuhn oddzielił naukę od refleksji, która na to miano jeszcze nie zasługuje, znajduje się bowiem na etapie przedparadygmatycznym, a zatem przednaukowym. Już pobieżna lektura prac poświęconych metodologii nauk politycznych uzmysławia, że dyscyplina ta nie spełnia jednego z warunków Kuhnowskiej paradygmatyczności. Wobec istnienia konkurencyjnych i wzajemnie się wykluczających paradygmatów brakuje w politologii powszechnej zgody wspólnoty naukowej co do tego, czym jest refleksja naukowa w obszarze zjawisk politycznych i w jaki sposób powinna się realizować ${ }^{2}$ I nie chodzi tu tylko o wielość podejść, które umożliwiają analizę przedmiotu badawczego z odmiennych perspektyw, kładących nacisk na różne niuanse zjawisk, lecz o spór dalece bardziej zasadniczy. Brakuje bowiem zgody co do natury obiektów świata społecznego, granic i możliwości ich poznania, a dopiero w konsekwencji co do tego, w jaki sposób powinien przebiegać proces badawczy, jaki zestaw procedur i standardów powinien obowiązywać, by poznanie to można było uznać za prawomocne. Podejście interpretacjonistyczne, czy raczej cała gama mocno zróżnicowanych interpretacjonistycznych strategii badawczych, wydaje się

1 T. Kuhn, Struktura rewolucji naukowych, Warszawa 2001, s. 33-35.

${ }^{2}$ Por. ibidem, s. 10. 
jedynie potwierdzać konkluzje wypływające z lektury Struktury rewolucji naukowych. Oto wielość podejść i brak jednolitego stanowiska odnośnie do zasad postępowania badawczego pogłębiają jedynie metodologiczny pluralizm politologii i świadczą (z pozoru) o jej przedparadygmatycznym charakterze jako dyscypliny naukowej czy raczej w tym kontekście przed-naukowej.

Problem ze Strukturą... polega jednak na tym, że dyskutuje ona paradygmatyczność w odniesieniu do przykładów z zakresu nauk przyrodniczych, zakładając tym samym milcząco, że prezentują one model nauki jako takiej. Stanowisko takie, zwane naturalizmem, przyjmuje, że wypracowane $\mathrm{w}$ ich obrębie standardy i rozstrzygnięcia $\mathrm{w}$ zakresie postępowania badawczego są $\mathrm{w}$ takim samym stopniu obowiązujące dla refleksji naukowej niezależnie od przedmiotu badania ${ }^{3}$. Pogląd ten opiera się na przyjętym milcząco założeniu, że kwestie ontologii przedmiotu poznania zostały jednoznacznie rozstrzygnięte, a treść tych rozstrzygnięć jest tożsama dla wszystkich obszarów refleksji naukowej. Takie stanowisko wyrasta $\mathrm{z}$ filozofii pozytywistycznej, stanowiącej swoistą kulminację określonych tradycji filozoficznych, które umożliwiły uformowanie się nowożytnej koncepcji nauki, a w konsekwencji spektakularny rozwój przyrodoznawstwa. W ten sposób ugruntował się metodologiczny gorset postępowania naukowego, który został domyślnie i mechanicznie nałożony na humanistykę i nauki społeczne, stając się podstawą tezy o ich zapóźnieniu.

Tymczasem interpretacjonizm, jako wyraz stanowiska antynaturalistycznego, wyrastającego z przekonania o zasadniczej odmienności nauk społecznych i przyrodoznawstwa, kontestuje ten punkt widzenia. Co ważne, sprzeciw ten nie jest próbą uniknięcia rygorów naukowości czy też kapitulacji wobec dyscypliny postępowania badawczego, w obliczu trudno poddających się jej osobliwości nauk społecznych. Przeciwnie, stanowi wyraz pogłębionej refleksji metodologicznej, która skłania do odrzucenia jednej tradycji filozoficznej na rzecz innej, będącej w stanie dostarczyć konstrukcji teoretycznych umożliwiających lepsze uchwycenie owych osobliwości ${ }^{4}$. Konsekwencją takiej strategii jest krytyczne odniesienie do założeń konstytuujących naturalistyczny program przy jednoczesnej rekonstrukcji ontologii nauk społecznych (w tym politologii) i wynikających z nich rozstrzygnięć epistemologicznych oraz metodologicznych. Taki stan rzeczy, zdaniem piszącego te słowa, uzasadnia posługiwanie się pojęciem paradygmatu do określenia przełomu, który dokonał się wraz z tak zwanym zwrotem interpretatywnym, choć jego znaczenie będzie odmienne od tego, które nadał mu Thomas Kuhn. Nie mamy tu bowiem do czynienia ze zmianą w obrębie samego zbioru pojęć i teorii tworzących podstawy danej nauki, lecz ze zmianą stanowiska, na którego gruncie te pojęcia i teorie są konstruowane. Kuhnowski paradygmat oznacza pewną powszechną praktykę badawczą, tworzącą się na podstawie akceptacji teorii, która na danym etapie rozwoju określonej dyscypliny naukowej jest w stanie w sposób zadowalający opisać zjawiska przez nią badane. Kuhn nie sta-

\footnotetext{
${ }^{3}$ Por. J. Giedymin, Problemy, założenia, rozstrzygnięcia: studia nad logicznymi podstawami nauk społecznych, Poznań 1964, s. 149.

${ }^{4}$ Filozoficzną tradycję uprawomocniającą paradygmat interpretacjonistyczny prezentuję szerzej w: M. Bachryj-Krzywaźnia, Interpretacjonizm narratywistyczny. Filozoficzna geneza, założenia metodologiczne i potencjat analityczny, w druku.
} 
wia jednak pytań o sposób ugruntowania danej teorii i praktyki badawczej ani o system przekonań, na gruncie których jawią się one jako prawomocne i pozwalające wytworzyć wiedzę, której treści uznane zostają za pewne i uzasadnione. Ta sfera jest konstytuowana przez spory filozoficzne - ontologiczne i epistemologiczne - a wielość obecnych w nich tradycji intelektualnych czyni je rzadko, jeśli w ogóle, rozstrzygalnymi. W tej sferze autor proponuje też poszukiwać linii demarkacyjnych przebiegających pomiędzy tradycjami naukowymi, zasługującymi na miano paradygmatów. Przenosi to w obszar rozważań, określanych przez Marka Bevira mianem meta-metodologicznych ${ }^{5}$.

Niniejszy artykuł jest próbą prezentacji specyfiki tak rozumianego paradygmatu interpretacjonistycznego, jednak nie przez pryzmat jego szczegółowych założeń. Byłoby to zresztą niemożliwe wobec olbrzymiego zróżnicowania w jego obrębie ${ }^{6}$. Przyjęta tutaj optyka zmierza raczej do uchwycenia tych cech, które z jednej strony wyjaśniają olbrzymią różnorodność interpretacyjnie zorientowanych praktyk badawczych, a z drugiej uzasadniają ich włączenie w obręb jednego pojęcia.

Nie dezawuując osiągnięć naturalistycznie zorientowanych podejść badawczych w naukach o polityce, autor skłania się raczej ku ontologii i epistemologii antynaturalistycznej w przekonaniu, że rozstrzygnięcia filozoficzne konstytuujące paradygmat naturalistyczny prezentują uproszczoną naturę zjawisk politycznych. Dokonywane na ich podstawie operacjonalizacje badawcze nie są wobec tego w stanie w pełni zrelacjonować osobliwości przedmiotu nauk o polityce. Wiele kwestii metodologicznych i problemów badawczych pozostaje $\mathrm{w}$ rezultacie niezauważonych czy też wyrzuconych poza obszar dociekań naukowych. Ponieważ interpretacjonizm zmienia tę optykę, wydaje się tą perspektywą analityczną, której ontologia i epistemologia - zdaniem autora - lepiej oddają złożoność zjawisk politycznych i sposób ich badania i która w stosunku do tradycji naturalistycznej poszerza instrumentarium badawcze politologa.

Aby uniknąć dowolności i eklektyzmu interpretacyjnie zorientowanych praktyk badawczych, a w konsekwencji źle uprawomocnionych rezultatów poznawczych, konieczne jest jednak zakreślenie granic, które pozwolą taktować podejście interpretacjonistyczne jako spójny i konsekwentny w swych założeniach nurt badań politologicznych. Wokół tego zagadnienia będą się ogniskować niniejsze rozważania i jako takie mają one zasadniczo charakter meta-metodologiczny. Formułowane niżej wnioski można wobec tego traktować jako szerokie ramy podejścia interpretacjonistycznego, w których powinny zostać osadzone poszczególne kategorie prowadzonej w jego nurcie analizy politologicznej tak, by stanowiła ona metodologicznie koherentne przedsięwzięcie.

5 „Meta-metodologia nauk o polityce jest filozofią nauk społecznych. Mówiąc konkretniej, meta-metodologia jest celową próbą teoretycznego wnioskowania o tym, w jakim przypadku, jakie aspekty polityki, jakimi metodami powinny być badane. Jest to próba wyjaśnienia, jaki rodzaj wiedzy i jaki rodzaj wyjaśnienia jest odpowiedni dla obiektów będących przedmiotem zainteresowań nauk o polityce". M. Bevir, Meta-methodology: clearing the underbrush, [w:] The Oxford Handbook of Political Methodology, red. J.M. Box-Steffensmeier, H.E. Brady, D. Collier, Oxford 2008, s. 48-49.

${ }^{6}$ Dvora Yanow wymienia w ramach interpretacjonizmu aż 34 różne metody badawcze. Por. D. Yanow, P. Schwartz-Shea, Introduction, [w:] Interpretation and Method. Empirical Research Methods and the Interpretive Turn, red. eidem, New York-London 2006, s. XX. 


\section{Konstruktywistyczna ontologia i niedualistyczna epistemologia interpretacjonizmu}

David Marsh i Paul Furlong, odwołując się do różnic ontologicznych i epistemologicznych, konfrontują ze sobą dwa odmienne podejścia badawcze - naukowe i hermeneutyczne. Przedstawiciele tego pierwszego zajmują pozycje naturalistyczne, stawiając na wyjaśnienie w kategoriach zależności przyczynowo-skutkowej jako celu działalności naukowej. Hermeneuci, jako wyraziciele stanowiska antynaturalistycznego, koncentrują się natomiast na znaczeniach i rozumieniu jako właściwych naukom społecznym przedmiocie i celu postępowania badawczego. Oba stanowiska różni także pogląd na istnienie świata i naszej wiedzy o nim. Podczas gdy podejście naukowe ufundowano na przekonaniu o jego obiektywnym istnieniu, hermeneuci utrzymują, że jest on społecznie i dyskursywnie konstruowany ${ }^{7}$.

Podobnie, choć w nieco bardziej systematyczny sposób, podchodzi do zagadnienia Piergorgio Corbetta, formułując trzy ściśle ze sobą powiązane pytania, na które odpowiedzi definiują specyfikę dwóch zasadniczych paradygmatów w naukach społecznych - empirycznego i humanistycznego. Pierwsze to pytanie ontologiczne - w jaki sposób istnieje rzeczywistość społeczna. Pytanie drugie - epistemologiczne, stawia kwestię relacji pomiędzy poznającym i poznawanym. Pytanie ostatnie - metodologiczne, to pytanie, $w$ jaki sposób rzeczywistość społeczna może być badana. $Z$ odpowiedzi na powyższe pytania wyłaniają się dwie zasadnicze różnice pomiędzy oboma paradygmatami. Pierwsza dotyczy sposobu istnienia rzeczywistości społecznej, druga natomiast relacji badacz i obiekt badania. Paradygmat empiryczny stoi na stanowisku obiektywnego, niezależnego od badacza istnienia zasadniczo poznawalnej rzeczywistości (naiwny realizm, krytyczny realizm), a w konsekwencji dualistyczno-obiektywistycznej epistemologii. Składają się na nią dwa założenia — badacz i obiekt badania nie zależą od siebie, oraz badanie może przebiegać $\mathrm{w}$ taki sposób, że przedmiot i podmiot badania nie wpływają na siebie. Paradygmat interpretacjonistyczny zajmuje natomiast w obu kwestiach stanowisko przeciwne. Zamiast realistycznej optuje za ontologią konstruktywistyczną, w której to ludzkie konstrukty rzeczywistości są tym, co faktycznie może być poznane, nie rzeczywistość sama w sobie. Kwestionuje przy tym dualistyczną relację badacz-obiekt badania, której towarzyszy również zacieranie granic między ontologią i epistemologią. Konsekwencją są oczywiście odmienne dyrektywy metodologiczne ${ }^{8}$. W podobny sposób

${ }^{7}$ D. Marsh, P. Furlong, Skóra, a nie sweter: ontologia i epistemologia w politologii, [w:] Teorie i metody w naukach politycznych, red. D. Marsh, G. Stoker, Kraków 2006, s. 17-32.

${ }^{8}$ Autor przytacza jeszcze inne zamienne terminy - obiektywizm $v$. subiektywizm, pozytywizm $v$. intepretacjonizm. Pierwsze człony tych trzech alternatyw opierają się na modelu nauki ukształtowanym $\mathrm{w}$ ramach przyrodoznawstwa i przeniesionym potem w obszar nauk społecznych, dlatego zasadne będzie dodanie do tej listy synonimów kolejnego - naturalizm $v$. antynaturalizm. Należy zauważyć, że choć na kolejnych stronach autor dyskutuje trzy perspektywy — pozytywistyczną, postpozytywistyczną, interpretacjonistyczną - to dwie pierwsze, $\mathrm{z}$ racji tożsamego stanowiska ontologicznego, należy uznać w takim samym stopniu za wariant w obrębie paradygmatu empirycznego. Różnica między nimi polega jedynie na tym, że w postpozytywistycznej perspektywie pewnemu osłabieniu ulega przekonanie o możliwości pełnego 
klasyfikacji dokonują również Donatella Della Porta i Michael Keating, charakteryzując na tej podstawie aż pięć głównych podejść teoretycznych w naukach społecznych, tworzących swoiste kontinuum na osi obiektywizm-subiektywizm9.

Ten pobieżny przegląd stanowisk i klasyfikacji pokazuje, że dwie (powiązane wzajemnie) kwestie odgrywają tutaj zasadniczą rolę. Po pierwsze, jest to ontologiczny status rzeczywistości społecznej, po drugie, zagadnienie relacji pomiędzy badaczem i jego obiektem oraz związana $\mathrm{z}$ nim rola podmiotu w procesie poznawczym i jego wpływ na rezultaty poznania. Konstytutywne dla paradygmatu interpretacjonistycznego, konstruktywistyczna ${ }^{10}$ ontologia i niedualistyczna epistemologia nie są oczywiście kwestią arbitralnego wyboru, nie wzięły się znikąd, w reakcji na rozczarowanie rygorami i możliwościami naturalizmu. Ich sformułowanie było możliwe na gruncie długiej i obszernej tradycji filozoficznej, w której zasadniczą rolę odgrywają dwa wątki — aprioryzm i antykartezjanizm. Ten pierwszy warunkuje ontologię interpretacjonizmu, drugi zaś jego epistemologię.

Choć różne warianty interpretacjonizmu będą swoje stanowisko w tych kwestiach niuansować, odwoływać się do różnych tradycji teoretycznych, zasadniczo powinny one jednak opierać się na antykartezjańskiej i apriorycznej charakterystyce sytuacji poznawczej. Jedynie taki jej ogląd jest bowiem w stanie uzasadnić konstruktywistyczny charakter ludzkiego poznania (w tym naukowego) i zakwestionowanie naturalistycznej ontologii. Nie oznacza to oczywiście, że każdy interpretatywnie zorientowany badacz będzie świadomie nawiązywał do tych pojęć, czy choćby w pełni znał i rozumiał ich sens, ewolucję i filozoficzną genezę. Zapewne twierdzenie takie będzie prawdą również w odniesieniu do naturalistycznie zorientowanych badaczy, którzy swoją praktykę badawczą wywodzą raczej ze zdroworozsądkowego i ogólnie podzielanego przeświadczenia, czym jest postępowanie naukowe, niż ze studiów nad pracami Davida Hume’a, Francisa Bacona, Isaaca Newtona czy przedstawicieli pozytywizmu logicznego albo realizmu krytycznego.

i obiektywnego poznania. P. Corbetta, Social Research. Theory, Methods and Techniques, London-Thousand Oaks-New Delhi 2003, s. 11-25; D. Yanow, Interpretive empirical political science: what makes this not a subfield of qualitative methods, „Qualitative Methods” 1, 2003, nr 2, s. 10-11.

${ }^{9}$ Są to: pozytywizm, postpozytywizm, konstruktywizm, intepretacjonizm, podejście humanistyczne. Autorzy wspierają się tu na regułach taksonomii zaproponowanej przez P. Corbettę (patrz przypis 8). Dwa pierwsze podejścia odpowiadałyby jego paradygmatowi empirycznemu, dwa ostatnie humanistycznemu, konstruktywizm zaś wydaje się perspektywą graniczną, posiadającą cechy obu pozostałych. Ten podział jawi się jako nie do końca poprawny, krytyczne odniesienia do ustaleń innych autorów nie wpisują się jednak w główny nurt narracji niniejszego tekstu, dlatego kwestie te zostaną tutaj pominięte. Por. D. Della Porta, M. Keating, How many approaches in the social science? An epistemological introduction, [w:] Approaches and Methodologies in the Social Sciences. A pluralist Perspective, red. eidem, Cambridge 2006, s. 19-28.

10 Pojawiający się już po raz drugi termin „konstruktywizm” ma niezwykle bogate i zróżnicowane znaczenie. Chodzi tu o myśli, różnice nie tylko pomiędzy szczegółowymi stanowiskami teoretycznymi, ale również te wynikające z ich potencjalnie zróżnicowanego zasięgu. Konstruktywizm może być bowiem rozumiany jako stanowisko z zakresu filozofii nauki lub, szerzej, jako stanowisko teoriopoznawcze, opisującej proces wytwarzania wiedzy jako takiej (obok naukowej również tej potocznej), rozstrzygając wobec tego zarówno o kontekście odkrycia, jak i kontekście uzasadnienia. Niemniej, w dalszej części tekstu zaproponowana zostanie, z pewnością niedoskonała i robocza, ogólna definicja konstruktywizmu poprzez wskazanie cech dla tego stanowiska konstytutywnych. 
Warto jednak sprecyzować istotę obu konkurencyjnych paradygmatów, aby poruszać się $\mathrm{w}$ nich nie tylko swobodnie, lecz także konsekwentnie, z respektem dla filozoficznych granic, których naruszanie może skutkować eklektyzmem i obniżeniem wiarygodności wyników badania naukowego.

\section{Aprioryzm — podstawa interpretacjonistycznej ontologii}

Aprioryzm, zwany także racjonalizmem metodologicznym, to stanowisko przyznające rozumowi, a nie doświadczeniu główną rolę w poznaniu. Skrajna wersja tego poglądu, uznająca za wartościową tylko wiedzę niezależną od doświadczenia, ma charakter historyczny. W swej wersji umiarkowanej pogląd ten jest natomiast równoznaczny z przekonaniem, że oprócz twierdzeń opartych na doświadczeniu uprawnione są również poznawczo twierdzenia niewynikające $\mathrm{z}$ doświadczenia, czyli aprioryczne ${ }^{11}$. Aprioryczność implikuje ścisłą ogólność i apodyktyczną konieczność, które wykluczają możliwość wyjątku i stanowią, że coś jest tak i nie może być inaczej ${ }^{12}$. W tej postaci występuje on właśnie między innymi w filozofii Kanta i ta jego forma umożliwiła późniejszy przełom antypozytywistyczny Diltheya, i w konsekwencji rozwój paradygmatu interpretacjonistycznego w całym jego zróżnicowaniu.

Identyfikując formy poznania apriorycznego Kant rozumie je jako pewne składniki poznania intelektualnego, jako element konstytucji podmiotu i element konstrukcyjny wszelkiego myślenia. Przedmioty dostępne poznaniu jawią się jako takie nie same z siebie, lecz dlatego, że to konstytucja podmiotu doprowadza do ich wystąpienia jako zjawisk $^{13}$. Aprioryczne struktury poznania wyłaniają przedmiot poznania ze strumienia nieuporządkowanych bodźców, ale w rezultacie przedmiot ten nie jest w umyśle przedstawiany jako noumen, rzecz sama w sobie, lecz jako konstrukcja - fenomen - będąca wynikiem pracy apriorycznych struktur umysłu. Treść przedstawień rzeczywistości jest zatem warunkowana właściwościami poznającego ją podmiotu. Jak ujmuje to Alicja Pietras, „zjawiska (rzeczy dla nas) ukazują jedynie pewne aspekty rzeczy takiej, jaką jest ona sama w sobie (w totalności swych określeń). Rzecz sama w sobie rozumiana jako totalność jest niepoznawalna" ${ }^{\prime 4}$.

Przyjęcie stanowiska apriorycznego oznacza w konsekwencji także zaakceptowanie pewnych granic poznania. Skoro bowiem możliwości umysłu ograniczone są przez jego władze poznawcze, to może on sobie przedstawić jedynie to, na co pozwala organizacja jego władz. To oznacza, że w procesie poznania nie jest dostępna rzeczywistość jako taka,

11 S. Blackburn, Oksfordzki słownik filozoficzny, Warszawa 1997, s. 27-28, A. Podsiad, Słownik terminów i pojęć filozoficznych, Warszawa 2000, s. 66.

12 P. Łaciak, Husserlowski model aprioryzmu: ontologizacja, deformalizacja i relatywizacja 'a priori', „Principia” 2007, nr 47/48, s. 54.

${ }^{13}$ L. Kleszcz, Boczne drogi: z genealogii filozofii hermeneutycznej, Wrocław 2004, s. 195; O. Höffe, Immanuel Kant, Warszawa 1995, s. 56.

14 A. Pietras, Być krytycznym - co oznacza dziś Kantowska teza o niepoznawalności rzeczy samych w sobie?, „Czasopismo Filozoficzne” 2007, nr 2, s. 6. 
niezależna od umysłu, lecz że w procesie tym umysł ma do czynienia jedynie z własnymi konstrukcjami. To, co jawi się nam zatem w poznaniu jako rzeczywistość, jest w istocie jej umysłowym konstruktem, dającym się uchwycić przez władze poznawcze wytworem umysłu. W apriorycznej perspektywie poznanie może bowiem dotyczyć tylko jakichś konstrukcji myślowych ${ }^{15}$. Należy jeszcze dodać, że dopuszczając istnienie poznania niepochodzącego z doświadczenia, Kant jednocześnie odrzucał koncepcję idei wrodzonych. Będąc w tej materii w opozycji do Kartezjusza, mówił raczej o epigenezie apriorycznych czynników poznawczych, to znaczy o tym, że nie są one dane od zawsze, lecz powstają niejako w reakcji na dane empiryczne, dzięki spontanicznej aktywności władz poznawczych. Poznanie aprioryczne w ujęciu Kantowskim, choć niezależne od doświadczenia, jest jednocześnie nierozerwalnie do niego odniesione i zespolone $\mathrm{z} \mathrm{nim}^{16}$. W rezultacie mamy do czynienia $\mathrm{z}$ aktywnym w procesie poznania podmiotem, a nie biernym, w którego umyśle jedynie odbija się w jak w zwierciadle poznawana rzeczywistość.

Przełom kopernikański Kanta w dziedzinie poznania, skutkujący koncepcją aktywnego poznawczo podmiotu, strukturyzujących właściwości ludzkiego umysłu, zwróceniem uwagi na podmiotowe uwarunkowania wiedzy oraz granice poznania, otwiera ten nurt refleksji, który umożliwił w rezultacie program konstruktywistyczny. Należy przy tym podkreślić, że terminy „,konstruktywizm”, „konstruktywistyczny” są dalekie od jednoznaczności, na co wpływa już choćby szerokie, transdyscyplinarne zastosowanie tego pojęcia. Sprawy nie ułatwia konstrukcjonizm, które to określenie często traktowane jako synonimiczne, okazuje się jednak opisywać stanowisko subtelnie różne od wspomnianego wcześniej konstruktywizmu ${ }^{17}$. Przy wszelkich różnicach i niuansach wynikających z dziedzinowej specyfiki i odmiennej genezy różnorodne konstruktywizmy mają jednak pewną część wspólną. Otóż badacze i teoretycy określani tym mianem wyrażają przekonanie, że obiekty zasiedlające rzeczywistość nie istnieją niezależnie od podmiotu poznającego. Proces poznawczy polega nie tyle na ich odkrywaniu, ile raczej konstruowaniu. Wiąże się to z poszukiwaniem struktur odpowiedzialnych za przebieg tego procesu: ich społecznej genezy, uwarunkowań i rozwoju ${ }^{18}$. Ogólnie rzecz biorąc konstruktywiści, przyjmując założenie, że człowiek konstruuje swoją wiedzę, kładą nacisk na różnorodne psycho-społeczno-kulturowe uwarunkowania wytwarzania ludzkiej wiedzy.

Kantowski aprioryzm oznaczał wprowadzenie do filozofii motywu, który silnie oddziaływał na rozwój myśli filozoficznej w XIX i XX wieku. Umożliwił wyłonienie się wielu koncepcji, które $\mathrm{z}$ jednej strony opierają się na Kantowskiej idei aktywności rozumu, z drugiej zaś dokonują jego relatywizacji, dynamizacji i historyzacji. W rezultacie kategorie umysłu, które w Krytyce czystego rozumu miały charakter uniwersalny,

15 Por. K. Ajdukiewicz, Zagadnienia i kierunki filozofii. Teoria poznania. Metafizyka, Kęty-Warszawa 2003, s. 58-59.

16 A. Przyłębski, Historyzacja a priori: zdrada czy produktywna kontynuacja filozofii transcendentalnej Kanta?, [w:] Immanuel Kant i świat współczesny, red. K. Świeżyński, Poznań 2004, s. 71.

${ }^{17}$ L. Miś, Konstruktywizm/konstrukcjonizm w socjologii, pracy socjalnej i terapii, http://www.iphils.uj.edu. pl/ lucjan.mis/Lucjan_Mis-Konstrukcjonizm_w_socjologii.pdf (dostęp: 20.05.2015).

18 M. Sikora, Problem reprezentacji poznawczej w nowożytnej i wspótczesnej refleksji filozoficznej, Poznań 2007, s. 21; E. Piotrowska, Społeczny konstruktywizm a matematyka, Poznań 2008, s. 10. 
uzyskują postać form zapośredniczonych kulturowo, historycznie zmiennych, uzależnionych od struktur językowych. W ten sposób zapoczątkowano całą linię niemieckiej filozofii, która wiązała struktury kategorialne z praktycznymi potrzebami poznającego podmiotu, związanymi z momentem historycznego i cywilizacyjnego rozwoju ${ }^{19}$. Aprioryzujący charakter rozumu zostaje wprawdzie zachowany, lecz traci swój ponadhistoryczny, uniwersalny charakter. Ta historyczna ewolucja Kantowskiej tradycji pozwala na ustanowienie pierwszej dystynkcji w obrębie teorii interpretacjonistycznych. Po jednej stronie będą te, które zakładają istnienie uniwersalnych, historycznie i kulturowo niezmiennych, wewnątrzpodmiotowych struktur aktywnych w procesie poznawczym, po drugiej stronie natomiast te, które wprawdzie identyfikują takie struktury, ale podkreślają ich dziejowy i kulturowy charakter. Taką rolę odgrywają na przykład tradycja, przesąd i dziejowy charakter poznania/rozumienia w hermeneutyce Gadamera. Choć stanowią one konstytutywne elementy poznania, to ich treść nie jest stała, mają charakter dziejowy, a więc zasadniczo zmienny. Podobne skutki rodzi pojęcie Lebenswelt (świata życia) Edmunda Husserla, którego fenomenologia i wyrosła z niej socjologia fenomenologiczna odegrały doniosłą rolę w krytyce naturalistyczno-pozytywistycznej socjologii empirycznej. Obiekty składające się na Lebenswelt, stanowiące przedmiot badań humanistycznych, pierwotne wobec zmatematyzowanego świata nauk przyrodniczych, są doświadczane $\mathrm{w}$ tak zwanym nastawieniu naturalnym, personalistycznym. Stanowią one pozateoretyczne źródło nauki, na nich jest ufundowane obiektywizujące, naukowe nastawienie przyrodnicze, ukierunkowane na pojmowanie świata jako powiązanego relacjami przyczynowo-skutkowymi i przedstawianego w sposób zmatematyzowany ${ }^{20}$. Wobec wielości i różnorodności światów życia rezultat tego uniwersalnie ludzkiego nastawienia naturalnego i ufundowanego na nim nastawienia przyrodniczego będzie kulturowo zdeterminowany. Zdaniem Husserla świat życia ma pewne przednaukowe struktury kategorialne, takie same jak te, które są zakładane przez nauki obiektywne. To spostrzeżenie prowadzi do ontologizacji i deformalizacji a priori, lokując aprioryczną ogólność i konieczność nie w podmiocie, lecz przedmiocie. W przypadku Kanta aprioryczna ogólność i konieczność oznaczają warunki narzucane przez umysł przedmiotom, bez których nie byłby w stanie ich sobie przedstawić (czyste formy naoczności i kategorie należące do konstytucji transcendentalnego podmiotu). U Husserla aprioryczność jest natomiast ugruntowana w przedmiocie; oznacza konieczne związki zachodzące między istotami i wyraża zależności istotnościowe. Miejsce Kantowskiej subiektywnej niezdolności do bycia przedstawionym inaczej zajmuje obiektywna konieczność niemożności bycia inaczej ${ }^{21}$. Elementy projektu filozoficznego Husserla, które oka-

19 A. Przyłębski, op. cit., s. 72-74; idem, Kant i hermeneutyka, „Przegląd Filozoficzny — Nowa Seria” 2004, nr 4, s. 307-308.

${ }^{20}$ D. Łukasiewicz, O pojęciu 'Lebensweltu' w fenomenologii Edmunda Husserla, „Przegląd Filozoficzny — Nowa Seria” 14, 2005, nr 2, s. 149-153; K. Święcicka, Husserl, Warszawa 1993, s. 103-108.

${ }^{21}$ P. Łaciak, Kan i Husserl a problem ontologizacji i deformalizacji 'a priori', „Folia Philosophica” 2007, $\mathrm{nr}$ 25, s. 116-118; M. Kornecki, Husserlowska koncepcja materialnego 'a priori', „Colloquia Communia” 2003, nr 74, s. 11-16. Istota i konsekwencje tego zwrotu są kwestią na tyle złożoną, że w tym miejscu możliwe jest jedynie ich zasygnalizowanie. 
zały się w tym kontekście szczególnie wpływowe, to przede wszystkim zainteresowanie procesami świadomościowymi, ponieważ kontakt z rzeczywistością dokonuje się zawsze poprzez procesy zachodzące w ludzkim umyśle. Dlatego też dany nam naocznie świat, jako rzecz oczywista sama przez się, który strukturalizuje działanie i myślenie człowieka, w pierwszej kolejności powinien się stać przedmiotem namysłu ${ }^{22}$.

Zakorzenienie interpretacjonizmu w tym nurcie refleksji filozoficznej, której kontynuacje i interpretacje owocują szeroką paletą stanowisk teoretycznych, stanowi również o pluralizmie wewnątrz samego paradygmatu interpretatywnego. Zostaje on pogłębiony dodatkowo ustaleniami w ramach poszczególnych dziedzin wiedzy o człowieku - psychologii, lingwistyki, antropologii czy budowanej między innymi na nich interdyscyplinarnej kognitywistyki, które dodatkowo mogą wzbogacić i doprecyzować interpretacjonistyczną perspektywę.

\section{Antykartezjanizm — podstawa intepretacjonistycznej epistemologii}

Pod sformułowaniem antykartezjanizm nie kryje się rzecz jasna stanowisko całkowicie i we wszystkim przeciwstawne systemowi filozoficznemu Kartezjusza. Byłoby ono zresztą w kontekście niniejszych rozważań nie do utrzymania, trudno bowiem sobie wyobrazić interpretacjonizm przy całkowitym zanegowaniu Kartezjusza, choćby ze względu na rolę, jaką ten ostatni przypisuje w poznaniu ludzkiemu umysłowi, pozwalającą określić go mianem racjonalisty. Towarzyszy temu jednocześnie sceptycyzm odnośnie do roli, którą odgrywają w poznaniu zmysły. Interpretacjonizm w swym konstruktywistycznym charakterze również przywiązuje uwagę do ludzkiego umysłu jako istotnego elementu sytuacji poznawczej. Robi to oczywiście w sposób całkowicie odmienny niż Kartezjusz. Używając powyższego terminu, autor ma na myśli tylko pewien aspekt tego systemu, który odcisnął wyraźne piętno na rozwoju filozofii nowożytnej i odegrał istotną rolę w kształtowaniu się paradygmatu pozytywistycznego. Chodzi tu mianowicie o wyłaniającą się z rozważań Kartezjausza oś poznawczą podmiot-przedmiot i ontologiczną odrębność obu jej członów.

Jednym z rezultatów systematycznego wątpienia Kartezjusza, które można śledzić $\mathrm{w}$ jego medytacjach, jest przekonanie, że myślenie, rozum, umysł są tym, co stanowi z jednej strony gwarancję istnienia, $\mathrm{z}$ drugiej zaś jego istotę ${ }^{23}$. Czymś zasadniczo odmiennym od człowieka jako rzeczy myślącej (res cogitans) jest rzeczywistość materialna (res extensa) z rozciągłością jako cechą konstytutywną. Te dwa rodzaje bytów, dwa rodzaje substancji, mają całkowicie wykluczające się charakterystyki i przynależą do zupełnie odmiennych porządków ${ }^{24}$. Świadomość i transcendentna względem niej zewnętrzność wespół wyczerpują metafizyczny obraz świata, ustanawiając przepaść pomiędzy myślącym

\footnotetext{
22 J.H. Turner, Struktura teorii socjologicznej, Warszawa 2005, s. 410-413.

23 R. Descartes, Medytacje o pierwszej filozofii, Kraków 1948, s. 22-23.

${ }^{24}$ Ibidem, s. 61-75.
} 
cogitatio i zewnętrznością ${ }^{25}$. W ten sposób konstytuuje się schemat sytuacji poznawczej zdefiniowanej poprzez przeciwstawienie poznającego podmiotu, który dzięki swoim istotowym właściwościom poznaje zewnętrzną i autonomiczną względem niego rzeczywistość w totalności jej określeń, przy czym rzeczywistość ta jest co do zasady poznawalna.

Konsekwencją stanowiska apriorycznego musi być odrzucenie powyższej metafizyki oraz ufundowanej na niej dualistyczno-obiektywistycznej epistemologii i w tym sensie będzie to stanowisko antykartezjańskie. Zakładając możliwość poznania obiektywnego, pozytywizm przyjmuje, że przy zastosowaniu odpowiednich procedur możliwe jest (i oczywiście pożądane) wyeliminowanie z poznania wszelkich wpływów podmiotowych, subiektywnych. Tymczasem niedualistyczna epistemologia interpretacjonizmu wyklucza w ogóle taką możliwość i wskazuje, że podmiot jest istotnym i nieodłącznym momentem każdego poznania, gdyż jego atrybuty konstytuują przedmiot rozumiany jako dostępny poznaniu fenomen. W tym świetle kartezjańska oś poznawcza podmiot-przedmiot nie jest niczym więcej niż iluzją, a obiektywny charakter poznania, jako wyabstrahowanego z elementów podmiotowych i subiektywnych dążenie do zgodności przedstawienia z rzeczywistością, jawi się jako cel nieosiągalny. Nieprzekraczalną granicę poznania ustanawia bowiem sam umysł, który nie jest sam dla siebie przejrzysty, posiada bowiem właściwości i struktury, które nie tylko umożliwiają procesy poznawcze, ale ponadto wywierają istotny wpływ na ich dynamikę i treść ich rezultatów. I w tym jeszcze sensie można mówić o antykartezjańskim charakterze interpretacjonistycznej epistemologii. Chodzi tu o zakwestionowanie mitu o uprzywilejowanym dostępie człowieka do wiedzy na własny temat, przekonaniu, że umysł niczego nie poznaje lepiej niż sam siebie.

\section{Konieczność szczególnych rozstrzygnięć teoretycznych w obrębie ogólnych założeń filozoficznych interpretacjonizmu}

Aprioryzm i antykartezjanizm, choć stanowią o granicach interpretacjonizmu i jego paradygmatycznej specyfice, wyznaczają jednocześnie obszar na tyle niejednorodny teoretycznie, że skutkuje to ogromną mnogością interpretacyjnie zorientowanych strategii badawczych, znajdujących oparcie w odmiennych teoriach.

Interpretacjonizm opiera się na przekonaniu, że ludzie działają na podstawie swoich wartości i przekonań. Interpretują rzeczywistość, nadają sens jej poszczególnym elementom i na tej podstawie podejmują działania. Są one więc zawsze w jakiś sposób poznawczo ugruntowane. Ukazując związek między przekonaniami i działaniami, nie przedstawiamy związków przyczynowo-skutkowych na wzór nauk przyrodniczych, nie odwołujemy się do przyczynowości sprawczej, lecz teleologicznej. By „zrozumieć działania, praktyki i instytucje, musimy pojmować znaczenia, przekonania i preferencje zaangażowanych jednostek" 26 .

${ }^{25}$ M. Czarnocka, Nowożytne pojęcie podmiotu a jego współczesne erozje, Warszawa 1998, s. 32-33.

${ }^{26}$ M. Bevir, R.A.W. Rhodes, Teoria interpretacjonistyczna, [w:] Teorie i metody w naukach politycznych..., s. 134-135. 
Sama rekonstrukcja punktu widzenia aktora nie wydaje się jednak wystarczającym zabiegiem. Dlaczego? Ponieważ obraz, który się w ten sposób uzyskuje, stanowi tylko zbiór niepowiązanych ze sobą elementów poznawczych (przekonań, wartości, preferencji), których związki pozostają nieodkryte. Nie wiadomo nic o ich wzajemnych powiązaniach, nie są znane struktury tego obrazu, istnieje tym samym ryzyko arbitralności i nieweryfikowalności wszelkich twierdzeń o ich teleologicznych związkach z praktykami, których tło stanowią. Mówiąc prościej - nie jesteśmy w stanie w pełny sposób zdać relacji z faktycznych sensów i znaczeń, w które zostają wyposażone przez subiektywną świadomość. Dopiero znając reguły i dynamikę procesu ich wyłaniania się jako elementów poznawczych ze strumienia doświadczeń podmiotu, a także mechanizmy atrybucji znaczeń i kategoryzacji doświadczeń, można w pełni zrozumieć sens nastawionych na cel działań aktora, bez ryzyka projekcji (nawet nieświadomej i nieintencjonalnej) własnych uprzedzeń, przesądów, sposobów strukturyzowania doświadczeń, preferencji i wartości. Aby jednak taki efekt uzyskać, intepretacjonizm musi zostać uzupełniony konkretną teorią antropologiczną, psychologiczną czy filozoficzną. W ten sposób ogólna wizja człowieka jako istoty rozumiejącej/interpretującej skonkretyzuje się w wizji istoty interpretującej w pewien określony sposób, według określonych reguł i wzorców. Pozostaje oczywiście pytanie: jakie teorie nadają się do tego celu? Czy mamy do czynienia w tym zakresie z całkowitą dowolnością i arbitralnością, czy może są jakieś granice, gdzie one przebiegają, skąd się wzięły? Otóż granice te stanowią właśnie aprioryzm i antykartezjanizm. Jeżeli te dwa stanowiska opisują najbardziej elementarną strukturę paradygmatu interpretacjonistycznego, to teoretycznie każda respektująca je teoria odnosząca się do społecznego funkcjonowania człowieka może zasilić arsenał teoretyczny interpretacyjnie zorientowanego badacza społecznego.

Należy tu jednak podkreślić, że pisząc o teoriach mogących zasilić intepretacjonizm, bardziej niż ich samorozumienie, samookreślenie na mapie filozofii nauki, interesujące będzie ich faktyczne stanowisko wobec aprioryzmu i antykartezjanizmu, nawet jeżeli teoria wyraża go tylko implicité. Przykładem może być strukturalizm, który choć aspiruje do miana teorii pozytywnej i w spostrzeżeniach Levi-Straussa pozwala wznieść się antropologii do poziomu ścisłości nauk przyrodniczych ${ }^{27}$, zawiera jednocześnie założenia korespondujące $\mathrm{z}$ filarami interpretacjonizmu. Aprioryzm przybiera tu postać bezimiennej, bezosobowej struktury, która determinuje właściwości języka i kultury, jak również relacji między nimi. Znaczenie słów oraz określonych praktyk życia społecznego jest kształtowane właściwościami tej struktury. Natomiast antykartezjanizm w tym przypadku uwidacznia się w tym, że każdy przedmiot, każde jego mentalne przedstawienie, nosi w sobie znamię właśnie tej struktury (języka), w której może być komunikowane. Jeżeli bowiem kultura i język mają określone właściwości strukturalne, to również wszelkie przedstawienia, które składają się na korpus ich wytworów, wszelkie pojęcia i idee (w tym również naukowe) będą odzwierciedlać oznaczone nimi byty nie $\mathrm{w}$ ich istocie i autonomicznych właściwościach, lecz tylko w tym zakresie, w jakim jest możliwe uchwycenie poprzez uniwersalną strukturę języka i kultury (umysłu). Będą więc

\footnotetext{
27 C. Levi-Strauss, Antropologia strukturalna, Warszawa 2000, s. 67.
} 
one dostępne ludzkiej refleksji, ludzkiemu poznaniu, zawsze w formie zapośredniczonej przez strukturalne właściwości aparatury pojęciowo-poznawczej człowieka, przez strukturalne właściwości kultury, w której obrębie są konceptualizowane, dostrzegane. Wprowadza to właśnie element konstrukcjonizmu ${ }^{28}$.

\section{Podsumowanie — problem podwójnej hermeneutyki}

Polityczność jest domeną i cechą wyłaniającą się z obszaru działań i relacji międzyludzkich. Jako taka nierozerwalnie wiąże się z człowiekiem, bez względu na to, czy będzie rozpatrywana jako aspekt, czy jako rezultat jego aktywności. Sfera polityki i zasiedlające ją obiekty nie istnieją zatem niezależnie od człowieka, nie posiadają w tym względzie atrybutów obiektów świata przyrodniczego, lecz jako obiekty specyficznie ludzkiego doświadczenia i działania mają naturę społeczną. Polityka (polityczność) stanowi bezsprzecznie element świata ludzkiego, świata życia, nabiera jego właściwości i tym samym wymyka się poznaniu uprzedmiotawiającemu i obiektywizującemu. Jest natomiast współkonstytuowana $\mathrm{w}$ aktach poznania i zależna od człowieka ${ }^{29}$. W przeciwieństwie do obiektów świata przyrodniczego obiekty świata politycznego, czy szerzej społecznego, mają charakter intencjonalny i celowościowy, są wyposażone w sensy i znaczenia, których źródeł należy upatrywać raczej w świecie życia niż ich ewentualnej materialnej substancji. Ta społeczno-ludzka natura obiektów świata polityki ma w istocie charakter aprioryczny, w sensie przytaczanej wcześniej aprioryczności Husserlowskiej, ugruntowanej w przedmiocie jako konieczność niemożności bycia inaczej. Jako związane z ludzkim doświadczeniem i strukturami zapośredniczającymi to doświadczenie obiekty te, takie jakimi zjawiają się w polu doświadczenia, bez względu na apodyktyczność owego doświadczenia, mają więc zawsze charakter ludzkich konstruktów, wytworów ludzkiego umysłu i jego struktur aktywnych w procesie poznania. Taki punkt widzenia jest jednym $z$ wariantów konstruktywizmu ${ }^{30}$. Podejście interpretacjonistyczne, korespondując w planie ontologicznym i epistemologicznym z tak postrzeganą naturą obiektów świata politycznego, wydaje się perspektywą teoretyczną właściwie nastrojoną filozoficznie do badania tego rodzaju obiektów.

Konsekwencją powyższych konstatacji musi być redefinicja sposobu konstruowania aparatu kategorialnego i celu postępowania badawczego nauki o polityce, wzorowanych na naukach przyrodniczych. Rzeczywistość polityczna i zachodzące w niej procesy nie będą tu prezentowane jako układ powiązanych zależnościami przyczynowo-skutkowymi, posiadających obiektywne właściwości obiektów. Należy ją zrozumieć raczej jako

28 Por. F. Jameson, The Prison-House of Language, Princeton-New York 1974, s. 109-110; T. Hawkes, Structuralism and Semiotics, London 1977, s. 17-18.

29 Por. A. Bronk, Filozoficzna hermeneutyka i kategoria obiektywności, [w:] Uniwersalny wymiar hermeneutyki, red. A. Przyłębski, Poznań 1997, s. 20-21.

${ }^{30}$ Mamy tu do czynienia ze stanowiskiem konstruktywistycznym w jego szerokim rozumieniu, nie tyle jako stanowiska z zakresu filozofii wiedzy naukowej i/lub potocznej, ile jako stanowiska odnoszącego się do rzeczywistości społecznej w ogóle. 
układ dążeń aktorów politycznych będących rezultatem indywidualnych i kolektywnych praktyk interpretacyjnych, które, prowadząc do wytworzenia subiektywnego obrazu rzeczywistości politycznej, stanowią podstawę celowej w nią interwencji i formułowania jej zawartości treściowej. Rola poszczególnych obiektów i procesów politycznych nie wynika $\mathrm{z}$ ich rzekomo stałych i obiektywnych atrybutów, lecz sensów i znaczeń nadanych im przez interpretujących aktorów politycznych.

Aprioryczny i antykartezjański charakter interpretacjonizmu skutkuje również pewnym sceptycyzmem wobec linii demarkacyjnej przebiegającej między psychologią i epistemologią, a w konsekwencji braku dystynkcji - czy raczej nakładania się - kontekstów odkrycia i uzasadnienia. Rozróżnienie to wynika z odmienności w rozumieniu problemu źródeł poznania. Ajdukiewicz wyodrębnia w tym kontekście psychologiczne i metodologiczne rozumienie tego zagadnienia. W pierwszym przypadku chodzi o faktyczną genezę pojęć, sądów i w ogóle myśli. W przypadku drugim jest to problem tego, jak można dojść do pełnowartościowego poznania rzeczywistości, jakimi metodami można dojść do zgodnego z prawdą i uzasadnionego jej poznania ${ }^{31}$. Szymon Wróbel ujmuje ten problem następująco: „Różnica między psychologią poznania a epistemologią streszcza się w różnicy między normą a faktem. O ile psychologia rozważa uwarunkowania faktycznych procesów poznawczych, dzięki którym pojedynczy człowiek staje się nośnikiem poznania, epistemologia stawia pytania o sposób i normy regulujące proces uzyskiwania wiedzy prawomocnej” ${ }^{32}$. Ta kardynalna zasada demarkacji — jak pisze Helena Kozakiewicz - wynika z kartezjańskiej metafizyki, wyróżniającej z uniwersum samodzielny obiekt, któremu przygląda się niezależny odeń subiekt ${ }^{33}$.

Tymczasem w kontekście zakreślonej wyżej perspektywy owa metafizyka i sposób konceptualizowania sytuacji poznawczej zostają zakwestionowane. W apriorycznym i antykartezjańskim stanowisku, a więc zakładającym istotność podmiotowych uwarunkowań poznania oraz brak separacji podmiotowo-przedmiotowej, owa demarkacja wydaje się mieć w konsekwencji charakter sztuczny i nieuprawniony. Zawiera się w niej bowiem sugestia, że oto podmiot poznania naukowego jest w stanie zawiesić czy transcendować swoje człowiecze uwarunkowania i uwikłania, by eliminując wszelką przypadkowość i partykularyzmy konkretnego zdarzenia poznawczego, uzyskać w ten sposób wiedzę pewną, zdeterminowną jedynie abstrakcyjnymi normami wywiedzionymi $z$ rozumu. Przy tym de facto same te normy wydają się wywiedzione nie przez konkretny empiryczny byt ludzki, lecz jakiś uogólniony, uniwersalny, ponadczasowy, wyekstrahowany $\mathrm{z}$ wszelkich konsekwencji ludzkiego bytowania $\mathrm{w}$ świecie, rozum. Jeżeli badacz interpretacjonista koncentruje się na subiektywnym punkcie widzenia aktora, a więc i na tym, jak on powstaje, odwołuje się do źródeł poznania w sensie psychologicznym. Przyjmuje zatem jakąś koncepcję procesów poznawczych, której nie może następnie zignorować czy wziąć w nawias, analizując problem prawomocności poznania, którego

31 K. Ajdukiewicz, op. cit., s. 30-32.

32 S. Wróbel, Odkrycie nieświadomości. Czy destrukcja kartezjańskiego pojęcia podmiotu poznającego?, Wrocław 1997, s. 24-25.

33 H. Kozakiewicz, Zwierciadło społecznego świata, Warszawa 1991, s. 27. 
wszak dokonuje również człowiek - badacz. Innymi słowy wyobrażenie o tym, czym powinna się cechować wiedza (kontekst uzasadnienia), by uznać ją za prawomocną, nie jest w stanie zneutralizować tego, jaka jest ona faktycznie (kontekst odkrycia). Małgorzata Czarnocka stoi na stanowisku, że

podmiot poznania naukowego nie jest szczególny, różny od podmiotów poznania innych typów [...] oba typy podmiotów mają takie same atrybuty. Uczony nie ma specjalnych władz poznawczych, które różniłyby go od podmiotu poznania zdroworozsądkowego [...] jak każdy człowiek, nie jest całkowicie świadomy, jakie cechy angażuje w poznanie, jaki charakter mają jego akty poznawcze, jakim zatem staje się podmiotem poznania w szczególnych sytuacjach egzystencjalnych ${ }^{34}$.

W tym kontekście twierdzenie Jerzego Kmity, że „charakterystyka genezy rozważanych jednostek czy systemów wiedzy naukowej, nie dostarcza żadnych danych - istotnych dla kwestii ich prawomocności” ${ }^{35}$, nie wydaje się tak oczywiste. Proces badawczy nie jest bowiem wolny od momentu interpretującego, a jego rezultat ma również charakter konstruktu. Odkrycie naukowe nie stanowi więc w tym świetle odkrycia prawdy o rzeczywistości takiej, jaką jest sama w sobie, wedle klasycznej formuły veritas est adaequatio rei et intellectus. Badacz interpretacjonista, konstruując naukowy obraz danego wycinka rzeczywistości, posługuje się bowiem strukturami poznawczymi analogicznymi do tych, które identyfikuje w ludzkim substracie przedmiotu swoich dociekań. Gdy przykładowo, podążając tropem Gadamerowskiej hermeneutyki, diagnozuje dziejowy charakter rozumienia, wskazując na specyficzną konfigurację prze(d)sądów i tradycji, uobecniających się w subiektywnym oglądzie rzeczywistości przez aktora politycznego, musi uwzględnić analogiczny wpływ tych czynników na treść formułowanych przez siebie samego wypowiedzi naukowych. Ignorowanie tych zależności oznaczałoby, że jest rzekomo w stanie zająć archimedesowy punkt, w którym, zachowując pełną neutralność, widzi rzeczy takimi, jakimi są same w sobie, że diagnozując wpływ określonych czynników na ludzkie poznanie, sam im nie podlega. Tymczasem jest on takim samym człowiekiem jak jego obiekt i nie ma możliwości transcendowania swoich specyficznie ludzkich ograniczeń i uwarunkowań poznawczych. W tym sensie trzeba się zgodzić z opinią, że „należy pozbyć się złudnego, archaicznego założenia, że możliwa jest neutralność badacza w odniesieniu do badanych przez niego obiektów"36.

W rezultacie obraz wiedzy wyłaniający się z powyższych rozważań zyskuje charakter podwójnej hermeneutyki: świat jest interpretowany przez aktorów społecznych, czego rezultat stanowi wiedza potoczna o tym świecie, subiektywny punkt widzenia aktora będący podstawą podejmowanych przez niego interwencji w rzeczywistość (pierwszy poziom hermeneutyczny). Następnie ta interpretacja potoczna jest poddawana interpretacji przez obserwatora-badacza (drugi poziom hermeneutyczny) ${ }^{37}$.

Obiekty zasiedlające świat polityczny jawią się w tej perspektywie nie jako realne, substancjalne byty, posiadające określony zestaw obiektywnych atrybutów, którymi oddzia-

\footnotetext{
${ }^{34}$ M. Czarnocka, Podmiot poznania i nauka, Wrocław 2003, s. 7-8.

35 J. Kmita, Kontekst odkrycia - kontekst uzasadnienia, „Studia Metodologiczne” 1974, nr 12, s. 29.

36 T. Sasińska-Klas, Najnowsze wyzwania w metodologii i badaniach w zakresie nauk społecznych, „Politeja" 2015, nr 36, s. 174.

37 Por. D. Marsh, P. Furlong, op. cit., s. 19.
} 
łują na aktorów politycznych. Przeciwnie, mają one charakter konstruktów, subiektywnych konstrukcji myślowych będących produktem swoistego metabolizmu poznawczego. Ponieważ możliwości umysłu pozostają ograniczone przez organizację jego władz poznawczych, podmiot poznający nie może przedstawić sobie rzeczywistości w sposób inny, niż pozwala mu na to sposób zorganizowania jego władz poznawczych. W konsekwencji umysł ma do czynienia zawsze $\mathrm{z}$ własnymi konstrukcjami, czy to w poznaniu potocznym czy też naukowym, zarówno na poziomie myślenia aktora politycznego o otaczającym go świecie, jak i na poziomie badacza analizującego ten świat polityczny w sposób naukowy. Perspektywa interpretacjonistyczna uwzględnia tę specyfikę poznania świata politycznego (czy szerzej społecznego), co oddala z pewnością perspektywę pewnej i ogólnej wiedzy, jaką mogłyby wytworzyć nauki o polityce na wzór nauk przyrodniczych. Obiektywizm - niekwestionowany wydawałoby się ideał wiedzy - jawi się tu nie tylko jako cel nieosiągalny, ale wręcz iluzja. Współczesne ustalenia filozofów, lingwistów, antropologów, psychologów i kognitywistów wyraźnie sugerują, że obraz sytuacji poznawczej, zawarty implicité $\mathrm{w}$ naturalistycznym modelu nauk społecznych, jest obrazem uproszczonym wręcz do granicy błędu. Podział obiektywizm-subiektywizm traci jednak tutaj na znaczeniu, czy może raczej gubi swój sens, jako możliwy jedynie na gruncie filozofii, której założenia obce są tej, na której ufundowany został interpretacjonizm.

\section{Bibliografia}

Ajdukiewicz K., Zagadnienia i kierunki filozofi. Teoria poznania. Metafizyka, Wydawnictwo Antyk, Kęty-Warszawa 2003.

Bachryj-Krzywaźnia M., Interpretacjonizm narratywistyczny. Filozoficzna geneza, założenia metodologiczne i potencjał analityczny, w druku.

Bevir M., Meta-methodology: clearing the underbrush, [w:] The Oxford Handbook of Political Methodology, red. J.M. Box-Steffensmeier, H.E. Brady, D. Collier, Oxford University Press, Oxford 2008.

Bevir M., Rhodes R.A.W., Teoria interpretacjonistyczna, [w:] Teorie i metody w naukach politycznych, red. D. Marsh, G. Stoker, Wydawnictwo Uniwersytetu Jagiellońskiego, Kraków 2006.

Blackburn S., Oksfordzki słownik filozoficzny, Książka i Wiedza, Warszawa 1997.

Bronk A., Filozoficzna hermeneutyka i kategoria obiektywności, [w:] Uniwersalny wymiar hermeneutyki, red. A. Przyłębski, Wydawnictwo Fundacji Humaniora, Poznań 1997.

Corbetta P., Social Research. Theory, Methods and Techniques, Sage Publications, London-Thousand Oaks-New Delhi 2003.

Czarnocka M., Nowożytne pojęcie podmiotu a jego współczesne erozje, Wydawnictwo IFiS PAN, Warszawa 1998. Czarnocka M., Podmiot poznania i nauka, Wydawnictwo Uniwersytetu Wrocławskiego, Wrocław 2003.

Della Porta D., Keating M., How many approaches in the social science? An epistemological introduction, [w:] Approaches and Methodologies in the Social Sciences. A pluralist Perspective, red. D. Della Porta, M. Keating, Cambridge University Press, Cambridge 2006.

Descartes R., Medytacje o pierwszej filozofii, Polska Akademia Umiejętności, Kraków 1948.

Giedymin J., Problemy, założenia, rozstrzygnięcia: studia nad logicznymi podstawami nauk społecznych, Wydawnictwo Naukowe PWN, Poznań 1964.

Hawkes T., Structuralism and Semiotics, Methuen \& Co Ltd, London 1977.

Höffe O., Immanuel Kant, Wydawnictwo Naukowe PWN, Warszawa 1995.

Jameson F., The Prison-House of Language, Princeton University Press, Princeton-New York 1974. 
Kleszcz L., Boczne drogi: z genealogii filozofii hermeneutycznej, Oficyna Wydawnicza Arboretum, Wrocław 2004.

Kmita J., Kontekst odkrycia - kontekst uzasadnienia, „Studia Metodologiczne” 1974, nr 12.

Kornecki M., Husserlowska koncepcja materialnego 'a priori', „Colloquia Communia” 2003, nr 74.

Kozakiewicz H., Zwierciadło społecznego świata, Wydawnictwo Naukowe PWN, Warszawa 1991.

Kuhn T., Struktura rewolucji naukowych, Fundacja Altheia, Warszawa 2001.

Levi-Strauss C., Antropologia strukturalna, Wydawnictwo KR, Warszawa 2000.

Łaciak P., Husserlowski model aprioryzmu: ontologizacja, deformalizacja i relatywizacja 'a priori', „Principia” 2007, $\mathrm{nr} 47 / 48$.

Łaciak P., Kant i Husserl a problem ontologizacji i deformalizacji 'a priori', „Folia Philosophica” 2007, nr 25.

Łukasiewicz D., O pojęciu 'Lebensweltu' w fenomenologii Edmunda Husserla, „Przegląd Filozoficzny — Nowa Seria" 14, 2005, nr 2.

Marsh D., Furlong P., Skóra, a nie sweter: ontologia i epistemologia w politologii, [w:] Teorie i metody w naukach politycznych, red. D. Marsh, G. Stoker, Wydawnictwo Uniwersytetu Jagiellońskiego, Kraków 2006.

Pietras A., Być krytycznym - co oznacza dziś Kantowska teza o niepoznawalności rzeczy samych w sobie?, „Czasopismo Filozoficzne” 2007, nr 2.

Piotrowska E., Społeczny konstruktywizm a matematyka, Wydawnictwo Naukowe Instytutu Filozofii UAM, Poznań 2008.

Podsiad A., Słownik terminów i pojęć filozoficznych, Instytut Wydawniczy PAX, Warszawa 2000.

Przyłębski A., Historyzacja a priori: zdrada czy produktywna kontynuacja filozofii transcendentalnej Kanta?, [w:] Immanuel Kant i świat współczesny, red. K. Świeżyński, Wydawnictwo UAM, Poznań 2004.

Przyłębski A., Kant i hermeneutyka, „Przegląd Filozoficzny - Nowa Seria” 2004, nr 4.

Sasińska-Klas T., Najnowsze wyzwania w metodologii i badaniach $w$ zakresie nauk społecznych, „Politeja” 2015, nr 36.

Sikora M., Problem reprezentacji poznawczej w nowożytnej i wspótczesnej refleksji filozoficznej, Wydawnictwo Naukowe Instytutu Filozofii UAM, Poznań 2007.

Święcicka K., Husserl, Wiedza Powszechna, Warszawa 1993.

Turner J.H., Struktura teorii socjologicznej, Wydawnictwo Naukowe PWN, Warszawa 2005.

Wróbel S., Odkrycie nieświadomości. Czy destrukcja kartezjańskiego pojęcia podmiotu poznającego?, Wydawnictwo Leopoldinum, Wrocław 1997.

Yanow D., Interpretive empirical political science: what makes this not a subfield of qualitative methods, „Qualitative Methods" 1, 2003, nr 2.

Yanow D., Schwartz-Shea P. Introduction, [w:] Interpretation and Method. Empirical Research Methods and the Interpretive Turn, red. D. Yanow, P. Schwartz-Shea, M.E. Sharpe, New York-London 2006.

\section{Źródła internetowe}

Miś L., Konstruktywizm/konstrukcjonizm w socjologii, pracy socjalnej i terapii, http://www.iphils.uj.edu. pl/ lucjan.mis/Lucjan_Mis-Konstrukcjonizm_w_socjologii.pdf. 


\section{Philosophical frames and premises of diversification of the interpretive approach}

Keywords: interpretive approach, apriorism, anti-Cartesianism, antinaturalism, constructivism, paradigm

\section{Summary}

The interpretive approach seems to be one of those umbrella terms that cover a multitude of extremely diversified research strategies. At first sight they seem to have nothing in common except the blurred term interpretation and skepticism about naturalism in social sciences. Nonetheless they have solid common philosophical underpinnings that constitute the peculiarity as well as pluralism of the interpretationist approach. The first one - apriorism - defines its ontology, the second one - anti-Cartesianism - specifies epistemology. Both create distinctiveness toward the objective and empirical standards of scientific investigation that deserve to be called not a mere approach but a paradigm. 